\title{
Gastric MALT lymphoma: clinical characteristics and prevalence of $H$. pylori infection in a series of 37 cases
}

\author{
J. P. Gisbert, B. Aguado'1, M. Luna, S. Nistal ${ }^{1}$, L. M. Asenjo, T. Reina ${ }^{2}$, A. Acevedo² and R. Arranz \\ Services of Gastroenterology, ${ }^{\prime}$ Hematology and ${ }^{2}$ Pathology. Hospital Universitario de La Princesa. Universidad \\ Autónoma. Madrid, Spain
}

\begin{abstract}
Objective: to perform a retrospective review of the clinical characteristics and prevalence of $H$. pylori infection in patients with gastric MALT lymphoma diagnosed in our hospital during the last 15 years.

Methods: patients with gastric MALT lymphoma diagnosed in our hospital during the last 15 years were retrospectively included. Demographic, clinic, analytic, endoscopic, and histological variables were reviewed. The extension study, the staging classification, and the presence of $H$. pylori infection were assessed.

Results: thirty-seven patients with gastric MALT lymphoma were identified. Mean age was 61 years, with $62 \%$ of males. The most common presentation symptom was dyspepsia (76\%), followed by digestive bleeding (11\%) and constitutional syndrome (8\%). At endoscopy, erosive lesions were identified in $41 \%$, and proliferative or exophytic lesions in $43 \%$. Most lymphomas were classified as low-grade (68\%). The stage distribution was EI for $56 \%$, EII for 13\%, EIII for 3\%, and EIV for 28\%. The prevalence of $H$. pylori infection (histology in all cases, rapid urease test in $19 \%$, and ${ }^{13} \mathrm{C}$-urea breath test in $24 \%$ ) was $46 \%$. When only lowgrade lymphomas in stage EI were considered, $H$. pylori prevalence increased to $55 \%$. When $H$. pylori infection was evaluated by ${ }^{13} \mathrm{C}$-urea breath testing (in addition to histology), the prevalence of $H$. pylori infection increased to $78 \%$.

Conclusions: it is probable that the reduced $H$. pylori prevalence found in some studies, as in ours, could be explained by false-negative results obtained when only one diagnostic method was used. Therefore, at least two (invasive) diagnostic methods should be performed. Furthermore, the performance of a non-invasive diagnostic method (such as a ${ }^{13} \mathrm{C}$-urea breath test) before the exclusion of $H$. pylori infection should be considered.
\end{abstract}

Key words: MALT. Mucosa-associated lymphoid tissue. Gastric lymphoma. Helicobacter pylori.

Recibido: 20-01-06.

Aceptado: 20-04-06.

Correspondencia: Javier P. Gisbert. Playa de Mojácar, 29. Urb. Bonanza. 28669 Boadilla del Monte. Madrid. Fax: 914022 299. e-mail: gisbert@meditex.es
Gisbert JP, Aguado B, Luna M, Nistal S, Asenjo LM, Reina T, Acevedo A, Arranz R. Gastric MALT lymphoma: clinical characteristics and prevalence of $H$. pylori infection in a series of 37 cases. Rev Esp Enferm Dig 2006; 98: 655-665.

\section{INTRODUCTION}

Non-Hodgkin's gastric lymphoma is a rare tumor accounting for less than $10 \%$ of lymphomas, and $3 \%$ of gastric neoplasms (1-5). However, primary gastric lymphoma is the most common extranodal lymphoma (1-5). Histological features of gastric low-grade lymphomas closely resemble mucosa-associated lymphoid tissue (MALT) (1-5). Nevertheless, most MALT lymphoma locations do not contain lymphoid tissue. For example, under normal conditions there is no evidence of organized lymphoid tissue in the gastric mucosa, where only the presence of a few lymphocytes has been described. However, as previously mentioned, this is the most common site for extranodal lymphomas. The clue to correctly explain this paradox is MALT development after $H$. pylori colonization (6).

Several lines of evidence establish a causal association between $H$. pylori infection and gastric MALT lymphoma, such as the high prevalence of the microorganism in this type of lymphoma and, particularly, the demonstration of tumor regression after $H$. pylori eradication. Therefore, the question of MALT lymphoma as an infectious disease has been recently proposed, and the answer was "partly yes" $(6,7)$.

However, nowadays the real prevalence of $H$. pylori in MALT lymphomas is unknown, as it varies between the various epidemiologic studies performed. Some studies showed that the prevalence of infection depends on the lymphoma's histological grade or the diagnostic method 
used, among others (8). A knowledge of the true prevalence of $H$. pylori in patients with MALT lymphoma is clinically relevant, as the detection of this organism will be followed by adequate eradication treatment, with consequent tumor regression in a high number of cases (1-5).

Our objective was to perform a retrospective review of the clinical characteristics and the prevalence of $H$. pylori infection in patients with gastric MALT lymphoma diagnosed in our hospital during the last 15 years.

\section{METHODS}

To carry out the present retrospective study all patients diagnosed with gastric MALT lymphoma in our center during the last 15 years (from January 1991 to December 2005) were initially identified. To this end, a triple search was carried out in the files of the Digestive, Hematology and Pathology units.

Subsequently, all medical records were recovered and a specifically designed questionnaire was completed, where the following variables were included:

1. Demographic variables: age, sex, smoking habit, alcohol intake, and history of neoplasm.

2. Clinical variables: most common reason for consultation (presentation symptom), and presence of B symptoms (fever, night sweats, and weight loss -more than $10 \%$ of body mass in the previous 6 months).

3. Physical exploration: presence of adenopathies (and their localization), oropharyngeal exploration, presence of hepatomegaly or splenomegaly.

4. Laboratory variables: human immunodeficiency virus (HIV) serology, Epstein-Barr virus serology, hepatitis $\mathrm{B}$ and $\mathrm{C}$ virus serology.

5. Endoscopic variables: type of macroscopic lesion (erosive, exophytic, hypertrophic), localization (antrum, body, diffuse), and characteristics of gastric biopsies obtained by the initial endoscopic exploration (number and localization).

6. Histological variables: low-grade and high-grade lymphoma classification.

7. Extension study: ORL exploration, chest X-rays, abdominal ultrasounds, gastrointestinal follow-through, cervical and thoraco-abdominal computerized tomography (CT) scans, and bone marrow citology/biopsy.

8. Staging: according to the Ann Arbor classification as modified by Musshoff, where stage EI indicates disease is confined to the stomach, EII implies the involvement of subdiaphragmatic lymph nodes, EIII means the involvement of lymph nodes on both sides of the diaphragm, and EIV refers to the involvement of distant organs. A differentiation between stages $\mathrm{EI}_{1}$ (confined to the mucosa and submucosa) and $\mathrm{EI}_{2}$ (extended over the submucosa) was only performed in those few cases where an endoscopic ultrasonogram was performed.

9. H. pylori infection: prevalence and diagnostic methods used in its evaluation.
Statistical analysis: for qualitative variables, the percentage was calculated (with its corresponding 95\% confidence interval or $95 \% \mathrm{CI}$ ). For quantitative variables, the arithmetic mean (and standard deviation) was provided. Although a comparison of the various variables was initially planned, only a descriptive analysis of variables could be done due to the limited number of patients included (37), resulting in reduced statistical power (that is, an elevated risk for beta errors).

\section{RESULTS}

From 1991 to 2005, 37 patients with gastric MALT lymphoma were identified and included in our study.

1. Demographic variables: the mean age of patients was $61 \pm 14$ years; $62 \%$ were males, $30 \%$ were smokers, and $16 \%$ had a history of alcohol abuse. In $11 \%$ a previous history of neoplasm existed.

2. Clinic variables: the most common reason for consultation (presentation symptom) was dyspepsia (76\%), followed by digestive bleeding (hematemesis or melena, $11 \%)$ and constitutional syndrome (8\%); $11 \%$ had B symptoms, fever $(5 \%)$, night sweats $(5 \%)$, and weight loss $(8 \%)$.

3. Physical exploration: adenopathies were identified in $22 \%$ of cases; of these, the distribution was: submaxillary $(0 \%)$, cervical $(14 \%)$, supraclavicular $(5 \%)$, axillary $(14 \%)$, and inguinal $(8 \%)$. The oropharyngeal exploration was normal in $88 \%$ of patients, whereas the pharynx was hyperemic in $6 \%$, and a hyperplasia of sublingual salivary glands was observed in $6 \%$ of patients. Hepatomegaly and splenomegaly were present in $11 \%$ and $5 \%$ of patients, respectively.

4. Laboratory variables: Epstein-Barr virus and HIV serology were negative in all cases, while the serology for hepatitis B and C virus was positive in 5 and $3 \%$ of cases, respectively.

5. Endoscopic variables: gastroscopy was normal in $16 \%$ of cases, whereas erosive lesions were identified in $41 \%$, and proliferative or exophytic lesions in $43 \%$. Endoscopic lesions were most commonly localized in the antrum (60\%), were observed in the body in only $35 \%$ of cases, and were diffuse in 5\%. The site for gastric biopsies obtained during the initial endoscopy was: antrum $(89 \%)$, body $(57 \%)$, incisure $(16 \%)$, and fundus $(11 \%)$. The mean number of biopsies obtained by endoscopy was $8 \pm 3$, with a range from 2 to 23 .

6. Histological variables: most lymphomas were classified as low-grade (25 patients, that is $68 \%$ ), whereas the remaining 12 patients (32\%) had a high-grade lymphoma. Patient characteristics by histological grade are summarized in table I.

7. Staging: stage distribution was: EI in 56\%, EII in $13 \%$, EIII in $3 \%$, and EIV in $28 \%$. Differentiation between stages $\mathrm{EI}_{1}$ and $\mathrm{EI}_{2}$ was only possible in 2 patients (both were $\mathrm{EI}_{1}$ ). 
Table I. Characteristics of gastric MALT lymphoma patients based on histological grade

\begin{tabular}{|c|c|c|}
\hline & $\begin{array}{l}\text { Low grade } \\
(n=25)\end{array}$ & $\begin{array}{l}\text { High grade } \\
(n=12)\end{array}$ \\
\hline Age (mean \pm SD) & $60 \pm 15$ & $65 \pm 13$ \\
\hline Sex (\% males) & 60 & 67 \\
\hline Smoking (\% smokers) & 36 & 17 \\
\hline Alcohol intake (\% drinkers) & 16 & 17 \\
\hline \multicolumn{3}{|l|}{ Diagnostic symptoms } \\
\hline Dyspepsia (\%) & 80 & 67 \\
\hline Digestive bleeding (\%) & 8 & 17 \\
\hline Constitutional syndrome (\%) & 8 & 8 \\
\hline B symptoms (\%) & 8 & 17 \\
\hline Fever $(\%)$ & 4 & 8 \\
\hline Night sweats (\%) & 4 & 8 \\
\hline Weight loss (\%) & 4 & 17 \\
\hline Hepatomegaly & 5 & 22 \\
\hline Splenomegaly & 2 & 10 \\
\hline $\mathrm{HIV}+(\%)$ & 0 & 0 \\
\hline $\mathrm{HBV}+(\%)$ & 4 & 8 \\
\hline $\mathrm{HCV}+(\%)$ & 4 & 0 \\
\hline \multicolumn{3}{|l|}{ Endoscopic features } \\
\hline Normal & 16 & 17 \\
\hline Erosive pattern & 40 & 42 \\
\hline Proliferative pattern & 44 & 41 \\
\hline \multicolumn{3}{|l|}{ Localization } \\
\hline Antrum (\%) & 58 & 67 \\
\hline Body (\%) & 38 & 33 \\
\hline Diffuse (\%) & 4 & 0 \\
\hline \multicolumn{3}{|l|}{ Stage } \\
\hline $\mathrm{El}(\%)$ & 49 & 70 \\
\hline Ell (\%) & 14 & 10 \\
\hline EIII (\%) & 5 & 0 \\
\hline $\operatorname{EIV}(\%)$ & 32 & 20 \\
\hline H. pylori positive (\%) & 40 & 58 \\
\hline
\end{tabular}

SD: standard deviation. HIV: human immunodeficiency virus. HBV: hepatitis B virus. $\mathrm{HCV}$ : hepatitis $\mathrm{C}$ virus.

8. H. pylori infection: the microorganism was initially detected in only 15 of 37 patients; therefore, all histological paraffin sections of $H$. pylori-negative patients were reviewed, and infection was identified in 2 further patients. Thus, $H$. pylori prevalence finally was $46 \%$ (31-62, 95\% CI). H. pylori prevalence in high-grade lymphomas was $58 \%(28-85,95 \% \mathrm{CI})$, but in low-grade lymphomas it was $40 \%(23-59,95 \% \mathrm{CI})$. When only low-grade lymphomas in stage EI were considered (11 patients), H. pylori prevalence was $55 \%$ (23-83, 95\% CI). The diagnosis of $H$. pylori infection was determined by histology (hematoxylineosin stain) in all cases. In 19 and 24\% a rapid urease test and a ${ }^{13} \mathrm{C}$-urea breath test, respectively, were performed besides histology. When $H$. pylori infection was detected both by histology and ${ }^{13} \mathrm{C}$-urea breath testing ( 9 patients), the prevalence increased to $78 \%$.

\section{DISCUSSION}

In the present retrospective study, 37 patients with gastric MALT lymphoma were included for the last 15 years.
Gastric MALT lymphoma is an uncommon neoplasm, with an incidence of $0.4-0.9$ cases per 100,000 persons (9). This tumor has been more frequently diagnosed during the last 50 years, with a mean age of $60-65$ years, and is 2-3 times more common in males $(10,11)$, as our results show (mean age 61 years, $62 \%$ males).

Gastric MALT lymphomas are often asymptomatic, and when symptoms are present, they are generally nonspecific, predominantly dyspeptic $(1-5,12,13)$. Therefore, the diagnosis of early gastric MALT lymphoma is difficult. In our patients the most common presentation symptom was dyspepsia (76\%). In patients with advancedstage lymphoma, anemia or a constitutional syndrome was present in $88 \%$ of our patients, these symptoms raising the possible diagnosis of gastric carcinoma (1$5,12,13)$. Finally, gastric MALT lymphoma may present with upper gastrointestinal bleeding in $20-30 \%$ of cases (1-5,12-14). In our experience, the presentation symptom was hematemesis or melena in $11 \%$ of patients.

Physical exploration in patients with gastric MALT lymphoma does not usually reveal any alterations (1$5,15)$, as was the case in most of our patients. Nonetheless, in high-grade lymphomas, clinical manifestations may be more evident. Thus, in advanced-stage lymphoma, hepatomegaly and splenomegaly can be detected (in 11 and $5 \%$ of our cases, respectively), or peripheral adenopathies can be found (in $22 \%$ of our patients).

A higher incidence of gastric MALT lymphoma in patients with hepatitis B virus has been described (16), as well as in patients with HIV $(17,18)$. All our patients were HIV-negative, whereas 3\% were infected by hepatitis B virus. Although this figure is higher than that reported for the general population, the small-size sample does not permit reliable conclusions to be drawn.

Endoscopic exploration may show a completely normal mucosa (this happened in $16 \%$ of our patients) or several endoscopic lesions. Three endoscopic patterns of gastric lymphoma have been described (ulcerative, exophytic and hypertrophic) (19). No hypertrophic pattern was found in our patients. Endoscopic lesions were more often localized in the antrum, as described in previous studies (1-5).

Gastric MALT lymphomas are divided up into highand low-grade lymphomas according to the percentage of blast cells in gastric biopsy samples. At the time of diagnosis, $75-80 \%$ of lymphomas are classified as low grade (1-5) (as happened in 75\% of our patients). It is very common to find both types of lymphoma in the same lesion, and it has been reported that up to one third of lowgrade lymphomas progress to high-grade lymphomas (20), suggesting that both lesions represent the same tumoral process.

The Ann Arbor classification as modified by Musshoff is probably the most widely used staging method (1-5) $-56 \%$ of our patients had stage EI. MALT lymphomas may invade not only other MALT tissues, but also lymph nodes and the bone narrow. In one Spanish study, $12 \%$ of low- 
Table II. Prevalence of $\boldsymbol{H}$. pylori infection in patients with MALT lymphoma

\begin{tabular}{|c|c|c|c|c|}
\hline Author & $\begin{array}{l}\text { Year of } \\
\text { publication }\end{array}$ & $n$ & $\begin{array}{c}\text { H. pylori } \\
\text { prevalence (\%) }\end{array}$ & $\begin{array}{l}\text { Diagnostic } \\
\text { method }\end{array}$ \\
\hline Nakamura et al. (24) & 2005 & 96 & 93 & $\mathrm{H}, \mathrm{S}, \mathrm{C}, \mathrm{RUT}, \mathrm{C}^{13}$ \\
\hline Lee et al. (25) & 2004 & 53 & 90 & $H$, RUT \\
\hline Yeh et al. (26) & 2003 & 20 & 85 & $H, C, R U T, C^{13}$ \\
\hline Lehours et al. (27) & 2003 & 56 & 71 & $\mathrm{H}, \mathrm{S}, \mathrm{C}$ \\
\hline Ruskone et al. (28) & 2001 & 44 & 77 & $\mathrm{H}, \mathrm{S}, \mathrm{C}$ \\
\hline Delchier et al. (29) & 2001 & 53 & 85 & S \\
\hline Hiyama et al. (30) & 2001 & 53 & 92 & $\mathrm{H}$ \\
\hline Cuttner et al. (31) & 2001 & 12 & 67 & $S$ \\
\hline Ben Rejeb et al. (32) & 2000 & 65 & 63 & $\mathrm{H}$ \\
\hline Arista-Nasr et al. (33) & 2000 & 54 & 57 & $\mathrm{H}$ \\
\hline Fischbach et al. (34) & 2000 & 35 & 100 & S \\
\hline Konturek et al. (35) & 2000 & 20 & 90 & $S, C^{13}$ \\
\hline Ohashi et al. (36) & 2000 & 23 & 61 & $\mathrm{H}, \mathrm{C}, \mathrm{RUT}$ \\
\hline Steinbach et al. (37) & 1999 & 34 & 82 & $\mathrm{H}, \mathrm{S}, \mathrm{RUT}$ \\
\hline Eck et al. (38) & 1999 & 60 & 98 & $\mathrm{H}, \mathrm{S}$ \\
\hline Yi et al. (39) & 1997 & 39 & 87 & $\mathrm{H}$ \\
\hline Dogusoy et al. (40) & 1999 & 32 & 72 & $H$ \\
\hline Bouzourene et al. (41) & 1999 & 31 & 58 & $\mathrm{H}$ \\
\hline Chang et al. (42) & 1999 & 53 & 75 & $\mathrm{H}$ \\
\hline Vallina et al. (43) & 1999 & 16 & 69 & $\mathrm{H}$ \\
\hline Jonkers et al. (44) & 1997 & 52 & 69 & $\mathrm{H}$ \\
\hline Oberhuber et al. (45) & 1997 & 89 & 84 & $\mathrm{H}$ \\
\hline Pavlick et al. (46) & 1997 & 16 & 69 & $H$ \\
\hline Eck et al. (47) & 1997 & 68 & 99 & $S$ \\
\hline Xu et al. (48) & 1997 & 53 & 55 & $\mathrm{H}$ \\
\hline Gisbertz et al. (49) & 1997 & 52 & 62 & $\mathrm{H}$ \\
\hline Nakamura et al. (50) & 1997 & 198 & 63 & $\mathrm{H}$ \\
\hline Chiang et al. (51) & 1996 & 19 & 92 & $\mathrm{H}, \mathrm{S}$ \\
\hline Herrera et al. (52) & 1996 & 27 & 85 & $\mathrm{H}$ \\
\hline Cammarota et al. (53) & 1995 & 39 & 87 & $\mathrm{H}, \mathrm{C}, \mathrm{RUT}$ \\
\hline Miettinen et al. (54) & 1995 & 22 & 59 & $\mathrm{H}$ \\
\hline Karat et al. (55) & 1995 & 12 & 50 & $H, S, R U T$ \\
\hline Calvert et al. (56) & 1995 & 12 & 42 & $\mathrm{H}$ \\
\hline Muller et al. (57) & 1995 & 45 & 80 & $\mathrm{H}$ \\
\hline Parsonnet et al. (58) & 1994 & 33 & 85 & $S$ \\
\hline Eidt et al. (59) & 1994 & 121 & 100 & $\mathrm{H}$ \\
\hline Fagioli et al. (60) & 1994 & 27 & 74 & $H$ \\
\hline Wotherspoon et al. (61) & 1) 1991 & 110 & 92 & $H$ \\
\hline
\end{tabular}

n: number of patients; $\mathrm{H}$ : histology; S: serology; C: culture; RUT: rapid urease test; $\mathrm{C}^{13}$ : urea breath test.

grade MALT lymphomas were diagnosed in stages III-IV, and there was bone narrow infiltration in $15 \%$ of patients (21). This conclusion was confirmed by other authors (22). In our experience, $31 \%$ of patients were in stages III-IV.

To carry out a correct classification of gastric MALT lymphoma the following is required: a minute physical exploration, paying special attention to: presence of adenopathies, splenomegaly, oropharyngeal lesions; laboratory studies, with hemogram and biochemical tests including proteinogram, immunoglobulins, and lactate dehydrogenase; chest X-rays; cervical and thoracoabdominal computerized tomography (CT) scans; and bone marrow citology/biopsy.

Finally, endoscopic ultrasounds constitute a fundamental exploration to accurately evaluate not only the le- sion's extent (infiltration of gastric wall) but also the presence of perigastric adenopathies (1-5). Furthermore, response to $H$. pylori eradication treatment can be predicted with this technique (23).

The prevalence of $H$. pylori infection in our patients was only $46 \%$, a figure lower than that generally described in the literature. In this respect, we recently carried out a systematic review of all 38 studies (including a total of 1,844 patients) that evaluate $H$. pylori prevalence in patients with gastric MALT lymphoma (24-61), and the overall prevalence was $79 \%$ (8) (although the results varied between $100 \%(34,38,59)$ and less than $50 \%$ $(55,56)$. Explanations for this diversity may be multiple and seem to depend, at least partly, on the number and type of techniques used to detect the infection, the histological grade of lymphoma, and the depth of tumor invasion. Thus, if appropriate diagnostic methods (in number and characteristics) are used, and if only low-grade lymphomas are considered, the prevalence of $H$. pylori infection increases to nearly $90 \%$, which reinforces the causal role of these bacteria in gastric MALT lymphoma (8). Nevertheless, in our study, when only low-grade lymphomas in stage EI were considered, H. pylori prevalence was still low (55\%).

The number of diagnostic methods used in our study was probably insufficient, as most patients were only evaluated by histology. A higher H. pylori prevalence has been described when serologic rather than histological methods were used (8). This probably could be explained by a decrease in bacterial colonization due to gastric atrophy and hypochlorhydria; however, antibodies against bacteria can be detected even years after mucosal clearance $(38,54)$. On the other hand, H. pylori gastric mucosa colonization is not uniform; thus, even in the presence of infection, microorganisms may not be detected if the biopsy is taken from a non-colonized mucosal area. Therefore, H. pylori detection by histology is highly dependent on the number of gastric biopsies $(38,51)$.

From the aforementioned results, we can deduce that in the presence of a negative result obtained by histology, a non-invasive diagnostic method such as the ${ }^{13} \mathrm{C}$-urea breath test or serology should be performed after definitely excluding $H$. pylori infection $(27,38)$. In this respect, when $H$. pylori infection was evaluated by ${ }^{13} \mathrm{C}$-urea breath testing as well as by histology (this happened in the last 9 patients), the prevalence of infection increased to $78 \%$. Thus, in our daily practice we usually use two biopsy-based methods (histology and a rapid urease test), and always perform a ${ }^{13} \mathrm{C}$-urea breath test to confirm negative cases.

To summarize, the accurately identification of $H$. pylori infection in patients with gastric MALT lymphoma is very relevant, as lymphoma regression has been demonstrated after $H$. pylori eradication. It is probable that the reduced $H$. pylori prevalence found in some studies, as in ours, could be explained by false-negative results ob- 
tained when only one diagnostic method was used. Therefore, one negative result obtained by histology (or rapid urease testing) should be followed by the use of a non-invasive diagnostic method before the exclusion of H. pylori infection.

\section{ACKNOWLEDGEMENT}

Supported in part by grants from the "Instituto de Salud Carlos III" (C03/02 and PI050109).

\section{REFERENCES}

1. Ahmad A, Govil Y, Frank BB. Gastric mucosa-associated lymphoid tissue lymphoma. Am J Gastroenterol 2003; 98: 975-86.

2. Fischbach W, Chan AO, Wong BC. Helicobacter pylori and gastric malignancy. Helicobacter 2005; 10 (Supl. 1): 34-9.

3. Al-Akwaa AM, Siddiqui N, Al-Mofleh IA. Primary gastric lymphoma. World J Gastroenterol 2004; 10: 5-11.

4. Farinha P, Gascoyne RD. Helicobacter pylori and MALT lymphoma. Gastroenterology 2005; 128: 1579-605.

5. Isaacson PG. Update on MALT lymphomas. Best Pract Res Clin Haematol 2005; 18: 57-68.

6. Gisbert JP. Is gastric lymphoma an infectious disease? Med Clin (Barc) 1998; 110: 56-61.

7. Isaacson PG, Spencer J. Is gastric lymphoma an infectious disease? Hum Pathol 1993; 24: 569-70.

8. Asenjo LM, Gisbert JP. Prevalencia de la infección por Helicobacter pylori en el linfoma MALT gástrico: una revisión sistemática. En prensa 2006.

9. Ullrich A, Fischbach W, Blettner M. Incidence of gastric B-cell lymphomas: a population-based study in Germany. Ann Oncol 2002; 13: 1120-7.

10. Cogliatti SB, Schmid U, Schumacher U, Eckert F, Hansmann ML, Hedderich J, et al. Primary B-cell gastric lymphoma: a clinicopathological study of 145 patients. Gastroenterology 1991; 101: 1159-70.

11. Weingrad DN, Decosse JJ, Sherlock P, Straus D, Lieberman PH, Filippa DA. Primary gastrointestinal lymphoma: a 30-year review. Cancer 1982; 49: 1258-65.

12. Amer MH, el-Akkad S. Gastrointestinal lymphoma in adults: clinical features and management of 300 cases. Gastroenterology 1994; 106: 846-58.

13. Ruskone-Fourmestraux A, Aegerter P, Delmer A, Brousse N, Galian A, Rambaud JC. Primary digestive tract lymphoma: a prospective multicentric study of 91 patients. Groupe d'Etude des Lymphomes Digestifs. Gastroenterology 1993; 105: 1662-71.

14. Pinotti G, Zucca E, Roggero E, Pascarella A, Bertoni F, Savio A, et al. Clinical features, treatment and outcome in a series of 93 patients with low-grade gastric MALT lymphoma. Leuk Lymphoma 1997; 26: 52737.

15. Brooks JJ, Enterline HT. Primary gastric lymphomas. A clinicopathologic study of 58 cases with long-term follow-up and literature review. Cancer 1983; 51: 701-11.

16. Gisbert JP, García-Buey L, Arranz R, Blas C, Pinilla I, Khorrami S, et al. The prevalence of hepatitis $C$ virus infection in patients with nonHodgkin's lymphoma. Eur J Gastroenterol Hepatol 2004; 16: 135-8.

17. Powitz F, Bogner JR, Sandor P, Zietz C, Goebel FD, Zoller WG. Gastrointestinal lymphomas in patients with AIDS. Z Gastroenterol 1997; 35: $179-85$

18. Imrie KR, Sawka CA, Kutas G, Brandwein J, Warner E, Burkes R, et al. HIV-associated lymphoma of the gastrointestinal tract: the University of Toronto AIDS-Lymphoma Study Group experience. Leuk Lymphoma 1995; 16: 343-9.

19. Seifert E, Schulte F, Weismuller J, de Mas CR, Stolte M. Endoscopic and bioptic diagnosis of malignant non-Hodgkin's lymphoma of the stomach. Endoscopy 1993; 25: 497-501.
20. Chan JK, Ng CS, Isaacson PG. Relationship between high-grade lymphoma and low-grade B-cell mucosa-associated lymphoid tissue lymphoma (MALToma) of the stomach. Am J Pathol 1990; 136: 1153-64.

21. Montalbán C, Castrillo JM, Abraira V, Serrano M, Bellas C, Piris MA, et al. Gastric B-cell mucosa-associated lymphoid tissue (MALT) lymphoma. Clinicopathological study and evaluation of the prognostic factors in 143 patients. Ann Oncol 1995; 6: 355-62

22. Thieblemont C, Berger F, Dumontet C, Moullet I, Bouafia F, Felman P, et al. Mucosa-associated lymphoid tissue lymphoma is a disseminated disease in one third of 158 patients analyzed. Blood 2000; 95: 802-6.

23. Sackmann M, Morgner A, Rudolph B, Neubauer A, Thiede C, Schulz $\mathrm{H}$, et al. Regression of gastric MALT lymphoma after eradication of Helicobacter pylori is predicted by endosonographic staging. MALT Lymphoma Study Group. Gastroenterology 1997; 113: 1087-90.

24. Nakamura S, Matsumoto T, Suekane H, Matsumoto H, Esaki M, Yao $\mathrm{T}$, et al. Long-term clinical outcome of Helicobacter pylori eradication for gastric mucosa-associated lymphoid tissue lymphoma with a reference to second-line treatment. Cancer 2005; 104: 532-40.

25. Lee SK, Lee YC, Chung JB, Chon CY, Moon YM, Kang JK, et al. Low grade gastric mucosa associated lymphoid tissue lymphoma: treatment strategies based on 10 year follow-up. World J Gastroenterol 2004; 10: 223-6.

26. Yeh HZ, Chen GH, Chang WD, Poon SK, Yang SS, Lien HC, et al. Long-term follow up of gastric low-grade mucosa-associated lymphoid tissue lymphoma by endosonography emphasizing the application of a miniature ultrasound probe. J Gastroenterol Hepatol 2003; 18: $162-7$

27. Lehours P, Ruskone-Fourmestraux A, Lavergne A, Cantet F, Megraud $\mathrm{F}$. Which test to use to detect Helicobacter pylori infection in patients with low-grade gastric mucosa-associated lymphoid tissue lymphoma? Am J Gastroenterol 2003; 98: 291-5.

28. Ruskone-Fourmestraux A, Lavergne A, Aegerter PH, Megraud F, Palazzo L, de Mascarel A, et al. Predictive factors for regression of gastric MALT lymphoma after anti-Helicobacter pylori treatment. Gut 2001; 48: 297-303.

29. Delchier JC, Lamarque D, Levy M, Tkoub EM, Copie-Bergman C, Deforges L, et al. Helicobacter pylori and gastric lymphoma: high seroprevalence of CagA in diffuse large B-cell lymphoma but not in low-grade lymphoma of mucosa-associated lymphoid tissue type. Am J Gastroenterol 2001; 96: 2324-8.

30. Hiyama T, Haruma K, Kitadai Y, Masuda H, Miyamoto M, Ito M, et al. Clinicopathological features of gastric-mucosa-associated lymphoid tissue lymphoma: a comparison with diffuse large B-cell lymphoma without a mucosa-associated lymphoid tissue lymphoma component. Clinicopathological Gastroenterol Hepatol 2001; 16: 734-9.

31. Cuttner J, Werther JL, McGlynn P, Chen A, Bodian C, Ogata S, et al. Seroprevalence of Helicobacter pylori infection in patients with lymphoma. Leuk Lymphoma 2001; 40: 591-7.

32. Ben Rejeb A, Kchir N, Bouali MR, Ebdelli N, Fsili R, Khediri F, et al. Gastric MALT lymphoma. A clinico-pathological study of 65 cases. Relationship to Helicobacter pylori. Tunis Med 2000; 78: 484-93.

33. Arista-Nasr J, Herrera-Goepfert R, Lazos-Ochoa M, Pichardo R. Histologic changes of the gastric mucosa associated with primary gastric lymphoma in endoscopic biopsy specimens. Arch Pathol Lab Med 2000; 124: 1628-31

34. Fischbach W, Jung T, Goebeler-Kolve M, Eck M. Comparative analysis of the Helicobacter pylori status in patients with gastric MALTtype lymphoma and their respective spouses. Z Gastroenterol 2000; 38: 627-30.

35. Konturek PC, Konturek SJ, Starzyska T, Marlicz K, Bielanski W, Pierzchalski P, et al. Helicobacter pylori-gastrin link in MALT lymphoma. Aliment Pharmacol Ther 2000; 14: 1311-8.

36. Ohashi S, Segawa K, Okamura S, Urano H, Kanamori S, Ishikawa H, et al. A clinicopathologic study of gastric mucosa-associated lymphoid tissue lymphoma. Cancer 2000; 88: 2210-9.

37. Steinbach G, Ford R, Glober G, Sample D, Hagemeister FB, Lynch PM, et al. Antibiotic treatment of gastric lymphoma of mucosa-associated lymphoid tissue. An uncontrolled trial. Ann Intern Med 1999; 131: 88-95.

38. Eck M, Greiner A, Schmausser B, Eck H, Kolve M, Fischbach W, et al. Evaluation of Helicobacter pylori in gastric MALT-type lymphoma: differences between histologic and serologic diagnosis. Mod Pathol 1999; 12: 1148-51. 
39. Yi Z, Ouyang Q, Li G. Investigation of relationship between primary gastric malignant lymphoma and Helicobacter pylori infection. Zhonghua Nei Ke Za Zhi 1997; 36: 442-5.

40. Dogusoy G, Karayel FA, Gocener S, Goksel S. Histopathologic features and expression of Bcl-2 and p53 proteins in primary gastric lymphomas. Pathol Oncol Res 1999; 5: 36-40.

41. Bouzourene H, Haefliger T, Delacretaz F, Saraga E. The role of Helicobacter pylori in primary gastric MALT lymphoma. Histopathology 1999; 34: 118-23.

42. Chang DK, Chin YJ, Kim JS, Jung HC, Kim CW, Song IS, et al. Lymph node involvement rate in low-grade gastric mucosa-associated lymphoid tissue lymphoma-too high to be neglected. Hepatogastroenterology 1999; 46: 2694-700.

43. Vallina E, Fresno F, Alonso JL, Madrigal B, Arribas JM. Incidence of primary gastric lymphoma and $\mathrm{H}$. pylori infection in the central zone of Asturias. An Med Interna 1999; 16: 175-7.

44. Jonkers D, Gisbertz I, de Bruine A, Bot F, Arends JW, Stobberingh E, et al. Helicobacter pylori and non-Helicobacter pylori bacterial flora in gastric mucosal and tumour specimens of patients with primary gastric lymphoma. Eur J Clin Invest 1997; 27: 885-92.

45. Oberhuber G, Kranz A, Dejaco C, Dragosics B, Mosberger I, Mayr $\mathrm{W}$, et al. Blood groups Lewis(b) and $\mathrm{ABH}$ expression in gastric mucosa: lack of inter-relation with Helicobacter pylori colonisation and occurrence of gastric MALT lymphoma. Gut 1997; 41: 37-42.

46. Pavlick AC, Gerdes H, Portlock CS. Endoscopic ultrasound in the evaluation of gastric small lymphocytic mucosa-associated lymphoid tumors. J Clin Oncol 1997; 15: 1761-6.

47. Eck M, Schmausser B, Haas R, Greiner A, Czub S, Muller-Hermelink HK. MALT-type lymphoma of the stomach is associated with Helicobacter pylori strains expressing the CagA protein. Gastroenterology 1997; 112: 1482-6.

48. Xu WS, Ho FC, Ho J, Chan AC, Srivastava G. Pathogenesis of gastric lymphoma: the enigma in Hong Kong. Ann Oncol 1997; 8 (Supl. 2): 41-4.

49. Gisbertz IA, Jonkers DM, Arends JW, Bot FJ, Stockbrugger RW, Vrints LW, et al. Specific detection of Helicobacter pylori and nonHelicobacter pylori flora in small- and large-cell primary gastric Bcell non-Hodgkin's lymphoma. Ann Oncol 1997; 8 (Supl. 2): 33-6.
50. Nakamura S, Yao T, Aoyagi K, Iida M, Fujishima M, Tsuneyoshi M. Helicobacter pylori and primary gastric lymphoma. A histopathologic and immunohistochemical analysis of 237 patients. Cancer 1997; 79: 3-11.

51. Chiang IP, Wang HH, Cheng AL, Lin JT, Su IJ. Low-grade gastric Bcell lymphoma of mucosa-associated lymphoid tissue: clinicopathologic analysis of 19 cases. J Formos Med Assoc 1996; 95: 857-65.

52. Herrera-Goepfert R, García-Marcano R, Zeichner-Gancz I. Helicobacter pylori and lymphoid follicles in primary gastric MALT-lymphoma in Mexico. Rev Invest Clin 1996; 48: 261-5.

53. Cammarota G, Tursi A, Montalto T, Papa A, Veneto G, Ruta F, et al. Clinical assessment of the relationship of Helicobacter pylori to gastroduodenal pathologies. A prospective analysis of 253 consecutive patients. Panminerva Med 1995; 37: 178-81.

54. Miettinen A, Karttunen TJ, Alavaikko M. Lymphocytic gastritis and Helicobacter pylori infection in gastric lymphoma. Gut 1995; 37: 471-6.

55. Karat D, O'Hanlon DM, Hayes N, Scott D, Raimes SA, Griffin SM. Prospective study of Helicobacter pylori infection in primary gastric lymphoma. Br J Surg 1995; 82: 1369-70.

56. Calvert R, Randerson J, Evans P, Cawkwell L, Lewis F, Dixon MF, et al. Genetic abnormalities during transition from Helicobacter-pyloriassociated gastritis to low-grade MALToma. Lancet 1995; 345: $26-7$.

57. Muller AF, Maloney A, Jenkins D, Dowling F, Smith P, Bessell EM, et al. Primary gastric lymphoma in clinical practice 1973-1992. Gut 1995; 36: 679-83.

58. Parsonnet J, Hansen S, Rodríguez L, Gelb AB, Warnke RA, Jellum E, et al. Helicobacter pylori infection and gastric lymphoma. N Engl J Med 1994; 330: 1267-71.

59. Eidt S, Stolte M, Fischer R. Helicobacter pylori gastritis and primary gastric non-Hodgkin's lymphomas. J Clin Pathol 1994; 47: 436-9.

60. Fagioli F, Rigolin GM, Cuneo A, Scapoli G, Spanedda R, Cavazzini $\mathrm{P}$, et al. Primary gastric lymphoma: distribution and clinical relevance of different epidemiological factors. Haematologica 1994; 79: 213-7.

61. Wotherspoon AC, Ortiz-Hidalgo C, Falzon MR, Isaacson PG. Helicobacter pylori-associated gastritis and primary B-cell gastric lymphoma. Lancet 1991; 338: 1175-6. 